\title{
Cicatrização de fevidas cutâneas e níveis séricos de corticosterona em ratos wistar submetidos ao enriquecimento ambiental ${ }^{*}$
}

\author{
FABIANA UEZ
}

\author{
André Silva Carissimi (Orientador - UFRGS) \\ Emerson Antônio Contensini (Co-Orientador - UFRGS)
}

Banca: Carlos Afonso de Castro Beck (UFRGS), João Antônio Tadeu Pigatto (UFRGS), Maria do Carmo Both (Parque Zoológico/RS).

A preocupação com o bem-estar dos animais utilizados na experimentação científica tem aumentado nos últimos anos bem como, a maneira que o estresse pode interferir nos resultados das pesquisas. Entre as técnicas utilizadas para minimizar o estresse e promover o bem-estar destaca-se o enriquecimento ambiental (EA), que visa propiciar um ambiente no qual o animal possa demonstrar comportamentos típicos da espécie. Nas espécies até hoje estudadas o uso do EA tem sido favorável com resultados positivos tanto no aspecto comportamental como fisiológico. O presente trabalho teve como objetivo avaliar o efeito do EA na recuperação pós-cirúrgica em Rattus norvergicus através da observação do nível de corticosterona sangüínea e o tempo de cicatrização, pela regressão do tamanho da ferida cirúrgica e posterior análise histopatológica. Ratos machos da linhagem Wistar foram separados em quatro grupos: sem procedimento cirúrgico e sem enriquecimento ambiental (grupo G1), com procedimento cirúrgico e sem enriquecimento ambiental (grupo G2), com procedimento cirúrgico e enriquecimento ambiental com mobiliário (grupo G3) e com procedimento cirúrgico e enriquecimento ambiental com interação social (grupo G4). No grupo G3, diferentes objetos (iglu, bloco de madeira e cano) foram colocados de forma seqüencial nas gaiolas enquanto que na gaiola do grupo G4 foi introduzido outro rato, macho, com a mesma idade e peso dos utilizados no experimento como forma de interação social. Os resultados demonstram que não houve diferença estatística significante em relação às áreas da ferida entre os grupos analisados (G2, G3 e G4) dentro do mesmo dia de observação. Entretanto, na avaliação histopatológica da cicatrização, houve diferença significativa na segunda semana de experimento entre as médias avaliadas do grupo G2 e o grupo G3 sendo que, este último apresentou melhor cicatrização quando comparado ao primeiro. Quanto ao nível de corticosterona observou-se diferença significativa do grupo G2 com relação aos demais grupos apenas na primeira semana. O grupo G2 apresentou também diferença significativa entre as semanas. Este resultado indica que, na primeira semana, os animais submetidos à cirurgia e mantidos em ambientes sem EA tiveram níveis elevados de corticosterona, compatível com situação de estresse, enquanto que os animais que também sofreram procedimento cirúrgico, mas foram mantidos em ambientes enriquecidos no pós-operatório, apresentaram níveis de corticosterona similares àqueles que não sofreram intervenção cirúrgica.

Descritores: enriquecimento ambiental, ratos, estresse, cicatrização, corticosterona.

Apresentada: 28 fevereiro 2005

*Dissertação de Mestrado n. 402 (Especialidade: Anestesiologia e Cirurgia Animal). 59f. Programa de Pós-graduação em Ciências Veterinárias [www.ufrgs.br/ppgcv], Faculdade de Veterinária, Universidade Federal do Rio Grande do Sul (UFRGS), Porto Alegre, RS/Brasil. CORRESPONDÊNCIA: F. Uez [fabiuez@hotmail.com]. 


\title{
Healing time of cutaneous wounds and serum corticosterone levels in wistar rats under enviromental enrichment*
}

\author{
FABIANA UEZ
}

\author{
André Silva Carissimi (Adviser - UFRGS) \\ Emerson Antônio Contensini (Co-Adviser - UFRGS)
}

Committee: Carlos Afonso de Castro Beck (UFRGS), João Antônio Tadeu Pigatto (UFRGS), Maria do Carmo Both (Parque Zoológico/RS).

The well-being of animals used on scientific research and the stress they go through have been worrying researches in the last years. Many procedures have been used to minimize the stress and promote the well-being of animals, mainly environmental enrichment (E.E.). This procedure aims to develop an ambient where the animals could show the typical behaviors of the species. The E.E. has been studied in several species and has shown positive results on the behavioral and physiologic aspects. The aim of this study was to evaluate the effect of E.E. in post-surgical recovery in Rattus norvergicus, observing the serum corticosterone levels and the healing time by the decrease in surgical wound size and through histopatological analyses. Male Wistar rats were separated in four groups: without surgical procedure and without E.E. (G1), with surgical procedure and without E.E. (G2), with surgical procedure and E.E. with furniture (G3) and with surgical procedure and E.E. with social interaction (G4). In the group G3, different kinds of objects (igloo, aspen blocks and a tube) were placed in the cages, in a sequencial form and in the cage of G4 another male rat of the same age and weight was introduced, and used for social interaction experience. The results showed that there was no significant statistical difference comparing the surgical wound area among the analysed groups (G2, G3 and G4) in the same day of observation. However, the histopatological analyses of the healing revealed a significant difference in the second week between the G2 and G3 groups mean, the latter showing improved healing. In relation to the serum corticosterone concentrations, there was a significant difference of G2 group related to the other groups only in the first week. The G2 group also showed a significant difference in between weeks. This result reveals that in the first week, the animals submitted to the surgical procedure and maintained in an ambient without E.E. had elevated corticosterone serum levels, compatible with an stressful situation, whereas the animals submitted to the same surgical procedure and maintained under E.E. post-surgically showed similar corticosterone levels than those that had not suffered surgical intervention.

Key words: environmental enrichment, rats, stress, cicatrization, corticosterone.

Presented: 28 February 2005

\footnotetext{
${ }^{* * *}$ Master's Thesis \# 402 (Field: Anestesiology and Animal Surgery). 59p. Graduate Program in Veterinary Sciences [www.ufrgs.br/ppgcv], Faculdade de Veterinária, Universidade Federal do Rio Grande do Sul (UFRGS), Porto Alegre, RS/Brazil. CORRESPONDENCE: F. Uez [fabiuez@hotmail.com].
} 